\title{
KETERAMPILAN KOMUNIKASI INTERPERSONAL DAN HASIL BELAJAR : SEBUAH STUDI KORELASI SISWA MENENGAH ATAS
}

\author{
Rima Mulyani" ${ }^{* 1}$, Diana Hernawati ${ }^{2}$, Mufti $\mathrm{Ali}^{3}$ \\ 1,2,3 Jurusan Pendidikan Biologi, Fakultas Keguruan dan Ilmu Pendidikan, \\ Universitas Siliwangi, Tasikmalaya \\ e-mail: "1rima.mulyani97@ gmail.com, ${ }^{2}$ hernawatibiologi@ unsil.ac.id, \\ 3muftiali.unsil@gmail.com
}

\begin{abstract}
ABSTRAK
Siswa memiliki potensi diri yang berbeda-beda karena memiliki keterampilan dan kecerdasan yang berbeda. Namun, untuk keterampilan komunikasi interpersonal selama ini belum banyak dijadikan sebagai salah satu faktor dalam meningkatkan ketercapaian hasil belajar. Untuk itu tujuan penelitian ini adalah untuk mengetahui korelasi antara keterampilan komunikasi interpersonal dan hasil belajar siswa. Penelitian ini dilaksanakan pada bulan Desember 2020 di kelas XI MIPA SMA Negeri 6 Tasikmalaya. Metode penelitian yang digunakan adalah korelasional dengan populasi seluruh kelas XI MIPA sebanyak 7 kelas. Sampel diambil dengan menggunakan teknik purposive sampling sebanyak 1 kelas dengan jumlah 36 orang siswa. Instrumen penelitian yang digunakan berupa angket keterampilan komunikasi interpersonal. Angket keterampilan komunikasi interpersonal terdiri dari 31 pernyataan menggunakan pengukuran skala Likert. Sementara hasil belajar didapatkan dari nilai ulangan materi tentang sel. Teknik analisis data menggunakan uji korelasi bivariat. Hasil analisis data dapat disimpulkan bahwa ada korelasi antara keterampilan komunikasi interpersonal dengan hasil belajar siswa pada materi sel dengan koefisien korelasi (R) sebesar 0,509 dengan kategori hubungan yang cukup kuat.
\end{abstract}

Kata Kunci: Hasil Belajar; Korelasi; Keterampilan Komunikasi Interpersonal.

\begin{abstract}
Students have different self-potential because they have different skills and intelligence. However, for interpersonal communication skills have not been widely used as one of the factors in improving the achievement of learning outcomes. Therefore, the purpose of this study is to find out the correlation between interpersonal communication skills and student learning outcomes. This research was conducted in December 2020 in class XI MIPA SMA Negeri 6 Tasikmalaya. The research method used is correlational with the population of the entire class XI MIPA as many as 7 classes. Samples were taken using purposive sampling techniques as many as 1 class with a total of 36 students. Research instruments used in the form of questionnaires of interpersonal communication skills. The interpersonal communication skills questionnaire consists of 31 statements using The Likert scale measurement. While the results of the study were obtained from the material replay value of the cell. Data analysis techniques use bivariate correlation tests. The results of the data analysis can be concluded that there is a correlation between interpersonal communication skills and student learning outcomes in cell material with a correlation coefficient $(R)$ of 0.509 with a fairly strong relationship category.
\end{abstract}


Keywords: Learning Outcomes; Correlation; Interpersonal Communication Skills.

\section{PENDAHULUAN}

Belajar merupakan proses dari suatu pengalaman yang didapatkan dari lingkungan sekitarnya. Belajar juga dilakukan untuk menyelesaikan problematika yang dihadapi secara terarah melalui proses pendidikan. Pendidikan mewadahi proses belajar dan pembelajaran yang dilakukan oleh siswa guna mengembangkan potensi diri (Sara, Suhendar, \& Pauzi, 2020; Pakpahan, Hernawati, \& ..., 2020).

Banyak cara untuk mengembangkan potensi diri dan sekolah merupakan tempat formal untuk mengembangkan diri. Salah satu bentuk pengembangannya dalam pendidikan adalah kemampuan komunikasi. Kemampuan ini diperlukan dalam proses belajar sebagai komunikasi interpersonal maupun sosial. Komunikasi interpersonal merupakan bentuk komunikasi sehari-hari yang dilakukan oleh makhluk sosial sebagai kemampuan dasar. Keterampilan komunikasi interpersonal mampu menyampaikan perasaan dan ide yang dimiliki dengan lebih terbuka kepada orang lain sehingga akan memudahkan siswa dalam menerima informasi (Setyaningrum \& Lestari, 2017).

Siswa dengan keterampilan komunikasi interpersonal tinggi akan cenderung menggunakan strategi yang efektif (Wijaya, 2013), cenderung lebih berani dalam menyampaikan pendapat, mampu berkomunikasi dengan baik dan mampu menyesuaikan diri dengan lingkungan tempat dia berada, sehingga akan memudahkannya dalam belajar, dan dapat membantu dalam meningkatkan hasil belajar (Utomo \& Harmiyanto, 2016). Keterampilan komunikasi interpersonal saling berhubungan dengan kepercayaan diri. Jika siswa memiliki keterampilan komunikasi yang baik, memudahkan siswa dalam belajar dan menyerap informasi sehingga membantu siswa dalam perubahan tingkah laku berupa pengetahuan, sikap, dan keterampilan. Siswa yang mampu menerapkan keterampilan komunikasi interpersonal akan berusaha untuk memaksimalkan segala kelebihannya ataupun potensi yang mereka miliki sehingga dapat membantu mencapai hasil yang optimal dalam setiap proses belajarnya.

Hasil survey awal menunjukkan kecenderungan yang selama ini terjadi masih rendahnya kemampuan komunikasi interpersonal pada banyak siswa. Terlebih untuk beberapa materi yang masih abstrak seperti materi sel. Konsep yang tidak dipahami dengan jelas berpengaruh terhadap kemampuan komunikasi interpersonalnya ketika metode pembelajaran dilakukan secara diskusi. Sementara prestasi belajar yang parameter awalnya dapat ditunjukkan dengan hasil belajar tidak hanya cukup dengan satu kemampuan saja, melainkan beragam kemampuan yang harus dikuasai siswa untuk ketercapaian tujuan pembelajaran. Dalam pembelajaran, ketika terjadi komunikasi interpersonal yang baik maka akan mengasilkan dampak positif dalam proses belajar. Dampak positif tersebut kemudian dapat menjadi motivasi bagi siswa untuk meningkatkan semangat belajar mereka sehingga mampu memperoleh hasil belajar yang diharapkan. Siswa yang memiliki keterampilan komunikasi interpersonal yang baik akan lebih mampu menjalin hubungan yang baik dengan orang lain (Erozkan, 2013). Sehingga hasil yang baik ini sebagai bagian dari proses sosial. Proses sosial yang berlangsung di dalamnya ialah proses komunikasi. Interaksi komunikasi seperti inilah yang akan mendatangkan kenyamanan baik antar siswa dengan guru maupun antar siswa dengan siswa lainnya dalam proses belajar mengajar. Untuk itu kemampuan komunikasi interpesonal itu dirasa penting untuk melihat hubungannya dengan hasil belajar siswa sebagai bentuk evaluasi akhir proses pembelajaran. 


\section{METODE}

Penelitian ini merupakan penelitian korelasional (Creswell \& Creswell, 2018; Fraenkel, 2010). Populasi dalam penelitian ini adalah seluruh kelas X MIPA SMAN 6 Tasikmalaya Tahun Ajaran 2019/2020 sebanyak 7 kelas dengan jumlah 248 siswa. Sedangkan sampel diambil sebanyak 1 kelas dengan jumlah 36 siswa secara purposive sampling.

Teknik pengumpulan data dengan teknik tes berupa kuesioner atau angket sebanyak 31 butir pernyataan. Sedangkan untuk hasil belajar diperoleh dari nilai ulangan materi sel Tahun Ajaran 2019/2020.
Teknik analisis data menggunakan korelasi bivariate pearson yang bertujuan untuk menguji hubungan antara dua variabel. Analisis dilakukan dengan menggunakan perangkat lunak SPSS versi 23 for windows dengan taraf signifikasi $5 \%$.

\section{HASIL DAN PEMBAHASAN}

Data yang diperoleh meliputi angket keterampilan komunikasi interpersonal dan hasil belajar yang diperoleh dari guru mata pelajaran biologi pada materi sel yang dapat dilihat pada Tabel 1.

Tabel 1. Statistik Hasil Penelitian

\begin{tabular}{|c|c|c|c|c|c|c|c|}
\hline \multicolumn{8}{|c|}{ Descriptive Statistics } \\
\hline & $\mathrm{N}$ & Minimum & Maximum & Mean & Median & Std. Deviation & Variance \\
\hline Keterampilan & 36 & 56 & 95 & 80,89 & 82,89 & 8,908 & 79,359 \\
\hline Komunikasi & & & & & & & \\
\hline Interpersonal & & & & & & & \\
\hline Hasil Belajar & 36 & 70 & 85 & 78,08 & 76,00 & 3,714 & 13,793 \\
\hline $\begin{array}{ll}\text { Valid } & N \\
\text { (listwise) } & \end{array}$ & 36 & & & & & & \\
\hline
\end{tabular}

Tabel 1 menjelaskan data statistik keterampilan komunikasi interpersonal siswa kelas XI MIPA 5 SMA Negeri 6 Tasikmalaya. Berdasarkan tabel tersebut, jumlah data 36 , nilai minimum yang diperoleh adalah 56, nilai maksimum 95, rata-rata 80,89 , median 82,50 , modus 84 , varians 79,359, dan standar deviasi 8,902 . Sedangkan untuk hasil belajar siswa dengan jumlah data 36 diperoleh rincian data statistik sebagai berikut: nilai minimum yang diperoleh adalah 70 , nilai maksimum
85 , rata-rata 76,08, median 76,00, modus 75 , varians 13,793 , dan standar deviasi 3,714 .

Selanjutnya untuk uji normalitas menggunakan uji Kolmogorov-Smirnov untuk mengetahui data berditribusi normal atau tidak, data berdistribusi normal apabila nilai signifikansi lebih dari 0,05. Adapun hasil uji normalitas keterampilan komunikasi interpersonal dengan hasil belajar siswa dapat dilihat pada Tabel 2 .

\section{Tabel 2. Hasil Uji Normalitas Keterampilan Komunikasi Interpersonal dan Hasil Belajar}

\begin{tabular}{cccccl}
\hline No & \multicolumn{1}{c}{ Data } & $\alpha 0,05$ & Signifikansi & $\begin{array}{c}\text { Hasil } \\
\text { Analisis }\end{array}$ & \multicolumn{2}{c}{ Kesimpulan Analisis } \\
\hline 1. & $\begin{array}{l}\text { Keterampilan } \\
\text { Komunikasi } \\
\text { Interpesonal }\end{array}$ & 0,05 & 0,200 & $\begin{array}{c}\text { Signifikansi } \\
>0,05\end{array}$ & $\begin{array}{l}\text { Ho diterima (Sampel telah } \\
\text { diambil dari populasi yang } \\
\text { berdistribusi normal }\end{array}$ \\
\hline 2. & Hasil Belajar & 0,05 & 0,200 & $\begin{array}{c}\text { Signifikansi } \\
>0,05\end{array}$ & $\begin{array}{l}\text { Ho diterima (Sampel telah } \\
\text { diambil dari populasi yang } \\
\text { berdistribusi normal }\end{array}$ \\
\hline
\end{tabular}

Berdasarkan Tabel 2, dapat disimpulkan bahwa sampel telah diambil dari populasi yang berdistribusi normal. Hal ini terlihat dari nilai signifikansi ke dua data yang memiliki nilai lebih besar dari 0,05.

Uji prasyarat selanjutnya yang dilakukan yaitu uji linearitas. Uji ini 
digunakan untuk mengetahui distribusi data penelitian memiliki hubungan yang linier atau tidak. Dalam penelitian ini uji linearitas yang digunakan adalah Test for linearity dalam perangkat lunak SPSS versi
23 for windows dengan taraf signifikansi 5\%. Adapun hasil uji linearitas keterampilan komunikasi interpersonal dengan hasil belajar siswa dapat dilihat pada Tabel 3.

Tabel 3. Hasil Uji Linearitas Keterampilan Komunikasi Interpersonal dan Hasil Belajar Siswa

\begin{tabular}{|c|c|c|c|c|c|c|c|}
\hline & & & $\begin{array}{l}\text { Sum of } \\
\text { Squares }\end{array}$ & Df & $\begin{array}{l}\text { Mean } \\
\text { Square }\end{array}$ & $\mathrm{F}$ & Sig. \\
\hline \multirow{5}{*}{$\begin{array}{l}\text { Hasil Belajar * } \\
\text { Keterampilan } \\
\text { Komunikasi } \\
\text { Interpersonal }\end{array}$} & Between & (Combined) & 310,417 & 23 & 13,496 & ,940 & ,569 \\
\hline & Groups & Linearity & 125,043 & 1 & 125,043 & 8,707 & ,012 \\
\hline & & $\begin{array}{l}\text { Deviation from } \\
\text { Linearity }\end{array}$ & 185,374 & 22 & 8,426 & ,587 & ,866 \\
\hline & Within C & & 172,333 & 12 & 14,361 & & \\
\hline & Total & & 482,750 & 35 & & & \\
\hline
\end{tabular}

Berdasarkan Tabel 3, hasil uji linearitas antara keterampilan komunikasi interpersonal dengan hasil belajar siswa yang mendapatkan nilai signifikansi 0,866 $>0,05$, maka dapat disimpulkan bahwa terdapat hubungan yang linear antara keterampilan komunikasi interpersonal dan hasil belajar siswa.

Berikut diagram scatterplot (bivar) dari keterampilan komunikasi interpersonal terhadap hasil belajar siswa (X dengan Y) dapat dilihat pada Gambar 1.

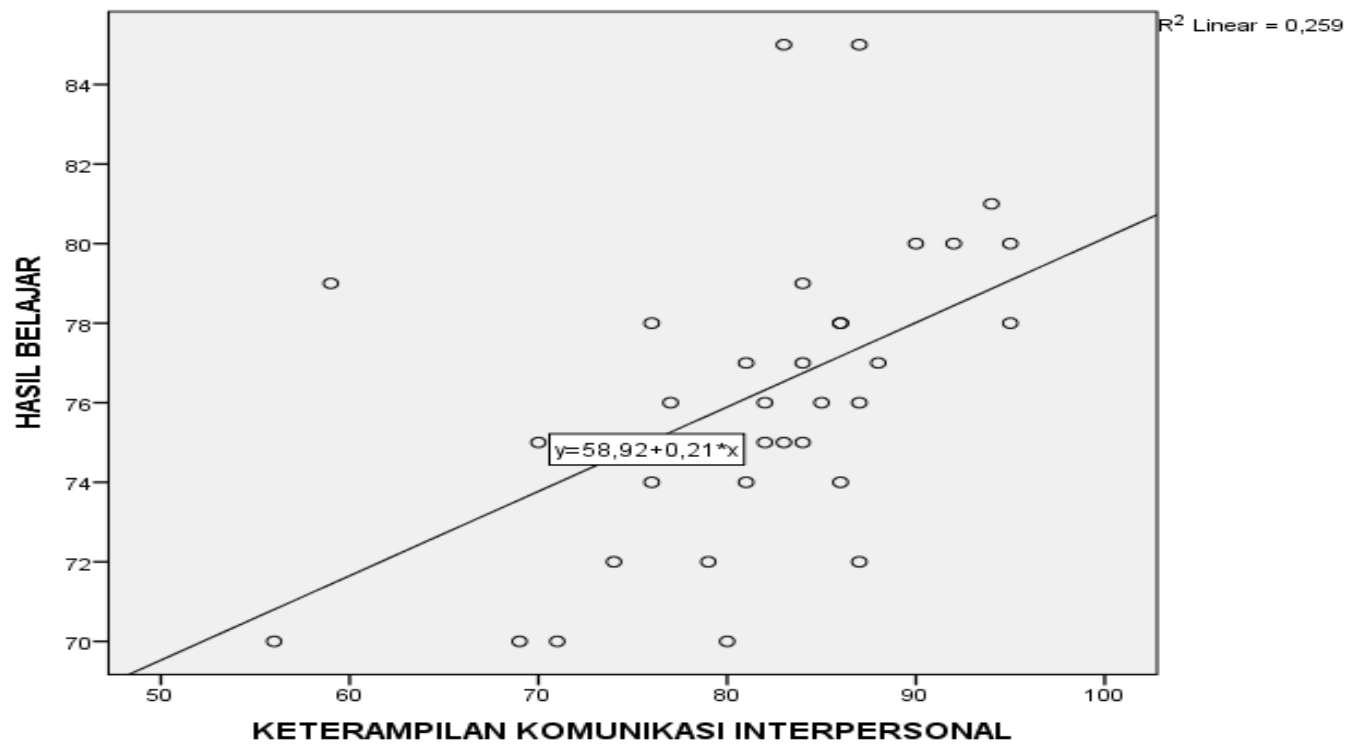

Gambar 1. Grafik Linearitas Keterampilan Komunikasi Interpersonal terhadap Hasil Belajar

Berdasarkan Gambar 1. tersebut menunjukan garis linear persamaan regresi yaitu nilai a sebesar 58,921 dan nilai b untuk $\mathrm{X}$ sebesar 0,212, sehingga persamaan regresinya yaitu $\hat{Y}=58,921+0,212 x$. Titiktitik plot data atau eror (penyimpangan dari nilai yang seharusnya diperoleh), terlihat arah hubungan linear positif yang dimiliki oleh keterampilan komunikasi interpersonal terhadap hasil belajar karena garis naik dari kiri ke arah kanan.

Untuk mengetahui ada atau tidaknya hubungan antara keterampilan komunikasi interpersonal dengan hasil belajar siswa, maka dilakukan uji hipotesis korelasi bivariat menggunakan SPSS versi 23 for windows. 
Tabel 4. Hasil Uji Regresi Korelasi Bivariat

\begin{tabular}{|c|c|c|c|c|c|c|c|c|c|}
\hline \multirow[b]{2}{*}{ Model } & \multirow[b]{2}{*}{$\mathrm{R}$} & \multirow[b]{2}{*}{$\begin{array}{c}\mathrm{R} \\
\text { Square }\end{array}$} & \multirow[b]{2}{*}{$\begin{array}{l}\text { Adjusted } \\
\text { R Square }\end{array}$} & \multirow[b]{2}{*}{$\begin{array}{l}\text { Std. Error of } \\
\text { the Estimate }\end{array}$} & \multicolumn{5}{|c|}{ Change Statistics } \\
\hline & & & & & $\begin{array}{c}\text { R Square } \\
\text { Change }\end{array}$ & F Change & df1 & df2 & $\begin{array}{c}\text { Sig. F } \\
\text { Change }\end{array}$ \\
\hline 1 &, $509^{a}$ & 259 & 237 & 3,244 & 259 & 11,885 & 1 & 34 & ,002 \\
\hline
\end{tabular}

Berdasarkan Tabel 4, nilai signifikansi sebesar $0,002<0,05$ yang berarti terdapat hubungan antara keterampilan komunikasi interpersonal dan hasil belajar siswa koefisien korelasi sebesar 0,509 yang berarti termasuk pada korelasi cukup kuat.

Berdasarkan hasil regresi korelasi bivariat yang digunakan untuk mengetahui korelasi antara keterampilan komunikasi interpersonal terhadap hasil belajar pada materi sel, didapatkan nilai signifikansi sebesar 0,002 yang berarti lebih kecil dari taraf signifikansi yang telah ditentukan yaitu 0,05. Sehingga, dapat diartikan ada korelasi yang sangat signifikan antara keterampilan komunikasi interpersonal terhadap hasil belajar pada materi sel. Selain itu, diperoleh juga dari hasil pengolahan data yaitu nilai koefisien korelasi (R) sebesar 0,509 yang masuk dalam kriteria cukup kuat. Oleh karena itu, untuk meningkatkan hasil belajar salah satu faktornya adalah meningkatkan keterampilan komunikasi interpersonal dengan memiliki rasa percaya diri yang tinggi agar mampu berinteraksi baik dengan guru maupun dengan siswa lain selama proses pembelajaran berlangsung, terbuka terhadap kritik yang datang dari orang lain untuk menghargai perbedaan pendapat, saling bekerja sama dengan siswa lain dalam memahami materi sel, mampu memberikan apresisi kepada teman yang memperoleh nilai tertinggi dikelas, mampu menghargai dirinya sendiri dan orang lain selama proses pembelajaran berlangsung, dapat menyesuaikan diri dengan lingkungan tempat dia berada dan berusaha untuk dapat memahami materi, baik bertanya kepada guru, melalui literatur maupun berdiskusi dengan teman agar mampu memahami materi sel dengan baik.
Berdasarkan hasil analisis data menggunakan uji $\mathrm{t}$ dengan bantuan aplikasi IBM SPSS 23 for windows, didapatkan nilai signifikansi sebesar 0,002. Dengan menggunakan taraf signifikansi 5\%, maka kesimpulan yang didapat adalah tolak $\mathrm{H}_{0}$ karena $0,002<0,05$. Hal ini menunjukkan bahwa ada hubungan secara parsial antara keterampilan komunikasi interpersonal dengan hasil belajar pada materi sel.

Adanya hubungan antara keterampilan komunikasi interpersonal dengan hasil belajar pada materi sel tidak terlepas dari upaya siswa untuk berperan aktif dalam proses pembelajaran, mengetahui bagaimana mereka memahami materi dalam pembelajarannya, mengetahui cara mereka berinteraksi dengan teman sebayanya, selalu berusaha untuk memahami materi dengan bertanya kepada guru dan berdiskusi dengan temannya. Siswa dengan keterampilan komunikasi interpersonal tinggi akan cenderung menggunakan strategi yang efektif dalam menjalankan proses belajarnya yang membuat hubungan di lingkungan tersebut terbina dengan baik sehingga proses belajar di sekolah menjadi semakin lancar, oleh karena itu perlunya kerjasama agar guru berhasil dalam mengajar di kelas (Larasati \& Marheni, 2019).

Keterampilan Komunikasi interpersonal akan mempererat hubungan antara guru dengan siswa, sehingga siswa mampu menyampaikan perasaan dan ide yang dimiliki dengan lebih terbuka kepada orang lain sehingga akan memudahkan siswa dalam menerima informasi tersebut dengan baik (Suhanti, Puspitasari, \& Noorrizki, 2018). Hargie, (2016); Gupta, Mehta, \& Sagar, (2015) mengemukakan bahwa keterampilan komunikasi interpersonal mencakup lima indikator, yaitu keterbukaan, empati, sikap dukungan, 
sikap positif dan kesetaraan. Keterbukaan adalah sebagai kemampuan untuk menghilangkan sikap tertutup terhadap masukan-masukan yang datangnya dari orang lain dan membuka diri pada orang lain, dan mengakui perasaan dan pikiran yang diungkapkan adalah milik sendiri dan bertanggungjawab atasnya. Empati adalah upaya untuk menempatkan diri sehingga seakan-akan ikut merasakan apa yang dirasakan orang lain. Sikap dukungan adalah masing-masing pihak yang berkomunikasi memiliki komitmen untuk mendukung terselenggaranya interaksi secara terbuka, dengan bersikap jujur kepada orang lain, dapat memahami perasaan orang lain dan dapat menerima pendapat orang lain. Sikap positif adalah dapat menghargai dirinya sendiri dan orang lain secara positif. Oleh karena itu, sikap positif muncul diawali dari adanya penghargaan terhadap diri sendiri dan orang lain. Kesetaraan adalah kondisi dimana kedua belah pihak yang berkomunikasi saling menghargai dan mempunyai sesuatu yang penting untuk diceritakan, serta dapat mengkomunikasikan perasaan dan rasa hormat pada perbedaan pendapat dan keyakinan. Dari kelima indikator keterampilan komunikasi interpersonal tersebut apabila dipelajari dan terus dilatih, akan memudahkan siswa dalam menerima informasi dengan baik (Maryanti, Zikra, \& Nurfarhanah, 2012).

Siswa dengan keterampilan komunikasi interpersonal yang tinggi (high regulatory) cenderung lebih berani dalam menyampaikan pendapat, mampu berkomunikasi dengan baik dan mampu menyesuaikan diri dengan lingkungan tempat dia berada, sehingga akan memudahkannya dalam belajar, dan dapat membantu dalam meningkatkan hasil belajar (Mufidah \& Asmawi, 2017). Keterampilan komunikasi interpersonal saling berhubungan dengan kepercayaan diri. Jika siswa memiliki keterampilan komunikasi yang baik, maka kepercayaan diri siswa akan tinggi. Semakin baik keterampilan komunikasi interpersonal, akan semakin tinggi pula kepercayaan dirinya. Siswa yang kurang percaya diri akan cenderung sedapat mungkin untuk menghindari situasi komunikasi (Fatriani, 2015). Berdasarkan penelitian Pratiwi \& Laksmiwati, (2016) siswa yang memiliki kepercayaan diri terhadap kemampuannya akan lebih mudah dalam menyusun strategi untuk memudahkannya dalam belajar, memiliki sikap berani dalam bersosialisasi baik di dalam kelas maupun luar kelas atau lingkungan sekolah, sedangkan siswa yang kurang memiliki kepercayaan diri akan merasa bahwa dirinya tidak mampu untuk berperan aktif serta akan menutup diri dan memilih menjadi pendengar yang baik. Sejalan dengan siswa dengan keterampilan komunikasi interpersonal yang baik cenderung memiliki kepercayaan diri yang tinggi sehingga akan memudahkannya berinteraksi dan mampu mengeluarkan pendapat tanpa keraguan. Dengan adanya hal tersebut siswa yang memiliki keterampilan komunikasi interpersonal yang baik cenderung memiliki kepercayaan diri, sehingga siswa akan berusaha untuk memaksimalkan segala kelebihankelebihan ataupun potensi yang mereka miliki sehingga dapat membantu mencapai hasil yang maksimal dalam setiap proses belajarnya.

Hasil penelitian yang telah dilakukan sejalan dengan penelitianpenelitian sebelumnya yang mengemukakan bahwa ada hubungan positif antara keterampilan komunikasi interpersonal dengan hasil belajar (Rianatha \& Sawitri, 2015). Semakin tinggi keterampilan komunikasi interpersonal maka semakin tinggi pula hasil belajar yang diperoleh, demikian pula sebaliknya apabila keterampilan komunikasi interpersonal siswa rendah maka hasil belajar yang diperoleh semakin rendah.

Dengan demikian, keterampilan komunikasi interpersonal merupakan salah satu cara untuk meningkatkan hasil belajar siswa (Lesmana, 2019). Adanya keterampilan komunikasi interpersonal ini akan membantu siswa dalam menjalin komunikasi yang baik dengan orang-orang disekitanya, mempunyai rasa percaya diri 
yang tinggi dalam menyampaikan pendapat dan ide yang dimiliki, mampu bekerja sama dalam memahami materi dan saling menghargai satu sama lain (Wisman, 2017). Dengan kemampuannya dalam berinteraksi membuat siswa mencoba untuk memulai dan mengarahkan upaya mereka untuk memperoleh pengetahuan dan keterampilan, sehingga dapat dikatakan bahwa keterampilan komunikasi interpersonal merupakan salah satu kunci utama dalam membantu memperoleh hasil belajar yang maksimal (Putriana \& Saragih, 2020; Pratiwi \& Laksmiwati, 2016). Hal ini sejalan dengan penjelasan Sapril, (2011) bahwa siswa dengan keterampilan komunikasi interpersonal yang baik, cenderung belajar secara aktif dan mencapai yang lebih baik di kelas. Sebaliknya siswa dengan keterampilan komunikasi interpersonal yang rendah, cenderung kurang baik dalam proses pembelajarannya.

Wood, (2013) menjelaskan bahwa dengan keterampilan komunikasi interpersonal, para siswa lebih mudah melaksanakan proses pembelajaran, memiliki keberanian dalam menyampaikan pendapat, mampu melakukan komunikasi yang baik dan dapat membantu meningkatkan hasil belajar mereka. Selain itu, mengemukakan bahwa keterampilan komunikasi interpersonal yang dikembangkan dengan baik akan membuat siswa memiliki kemampuan untuk mengarahkan pengalaman belajar mereka lebih aktif dalam berbagai cara.

Berdasarkan hasil analisis, temuan, dan pembahasan dari penelitian yang telah dilakukan dan didukung oleh penelitian-penelitian sebelumnya dapat disimpulkan bahwa keterampilan komunikasi interpersonal sering digunakan oleh guru dalam proses komunikasi untuk meningkatkan pengetahuan siswa karena dianggap lebih tepat dan efektif untuk melatih keberanian siswa dalam menyampaikan ide maupun gagasan, untuk melatih keberanian siswa dalam berinteraksi dengan guru maupun dengan siswa lain, terjalinnya hubungan yang baik dengan keluarga, guru maupun dengan teman sebaya, saling menghargai perbedaan pendapat dan saling bekerja sama dalam proses belajar, saling mendukung dan memberikan apresiasi kepeda teman. Dimana dengan menerapkan keterampilan komunikasi interpersonal pada akhirnya dapat membantu meningkatkan hasil belajar mereka. Keterampilan komunikasi interpersonal yang dikembangkan dengan baik dapat membantu meningkatkan hasil belajar, karena perannya sangat penting dalam membantu memudahkan siswa melaksanakan proses belajar. Dengan demikian, keterampilan komunikasi interpersonal akan sangat membantu dalam kegitan belajar mengajar karena komunikasi interpersonal merupakan sesuatu keterampilan dalam berinteraksi yang dipelajari dan tidak dibawa sejak lahir melainkan perlu dilatih.

Selanjutnya, untuk penentuan kategorisasi keterampilan komunikasi interpersonal dapat digambarkan dalam diagram kategorisasi yang dapat dilihat pada Gambar 2. 


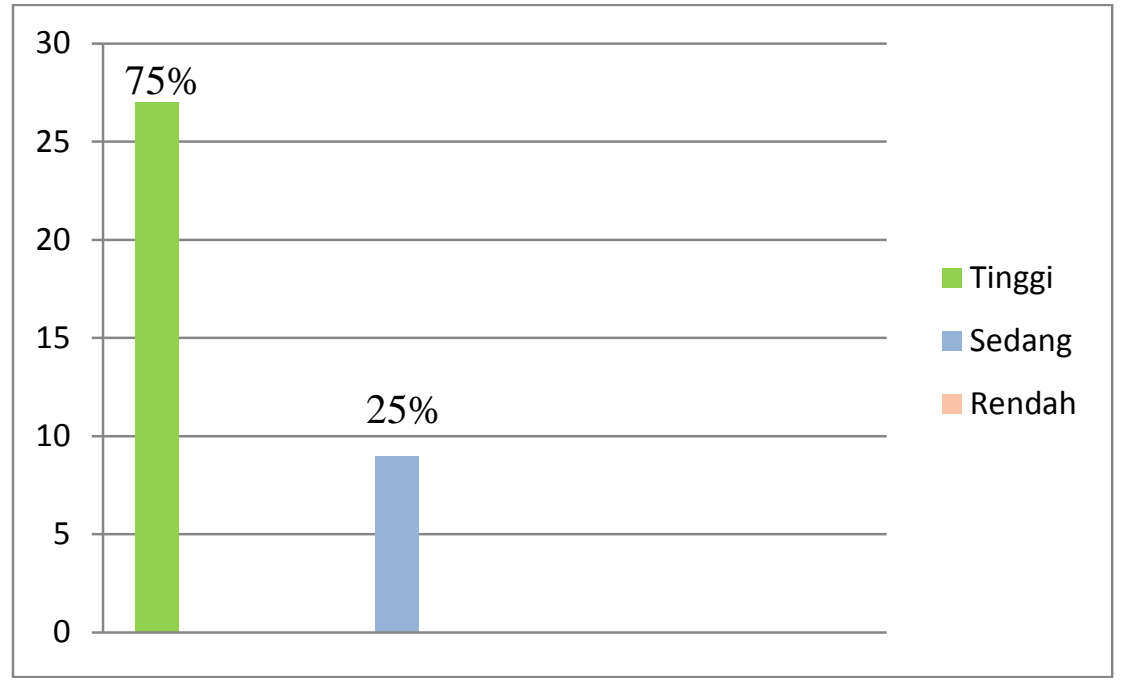

Gambar 2. Diagram Kategorisasi Keterampilan Komunikasi Interpersonal

Berdasarkan hasil kategorisasi keterampilan komunikasi interpersonal siswa pada Gambar 2, siswa yang memiliki keterampilan tinggi sebanyak 27 orang (75\%). Kemudian siswa yang masuk kedalam kategori sedang sebanyak 9 orang (25\%), dan siswa tidak ada masuk kedalam kategori rendah. Jadi dapat disimpulkan bahwa, kecenderungan variabel keterampilan komunikasi interpersonal siswa di kelas XI MIPA 5 berada pada kategori tinggi, yaitu sebanyak 27 orang (75\%) dari jumlah sampel berjumlah 36 orang.

Selanjutnya, berdasarkan hasil penelitian, terdapat perbedaan dari kemampuan komunikasi interpersonal siswa dalam menjawab pernyataan indikator kemampuan komunikasi interpersonal. Pencapaian skor rata-rata perindikator keterampilan komunikasi interpersonal dapat dilihat pada Gambar 3.

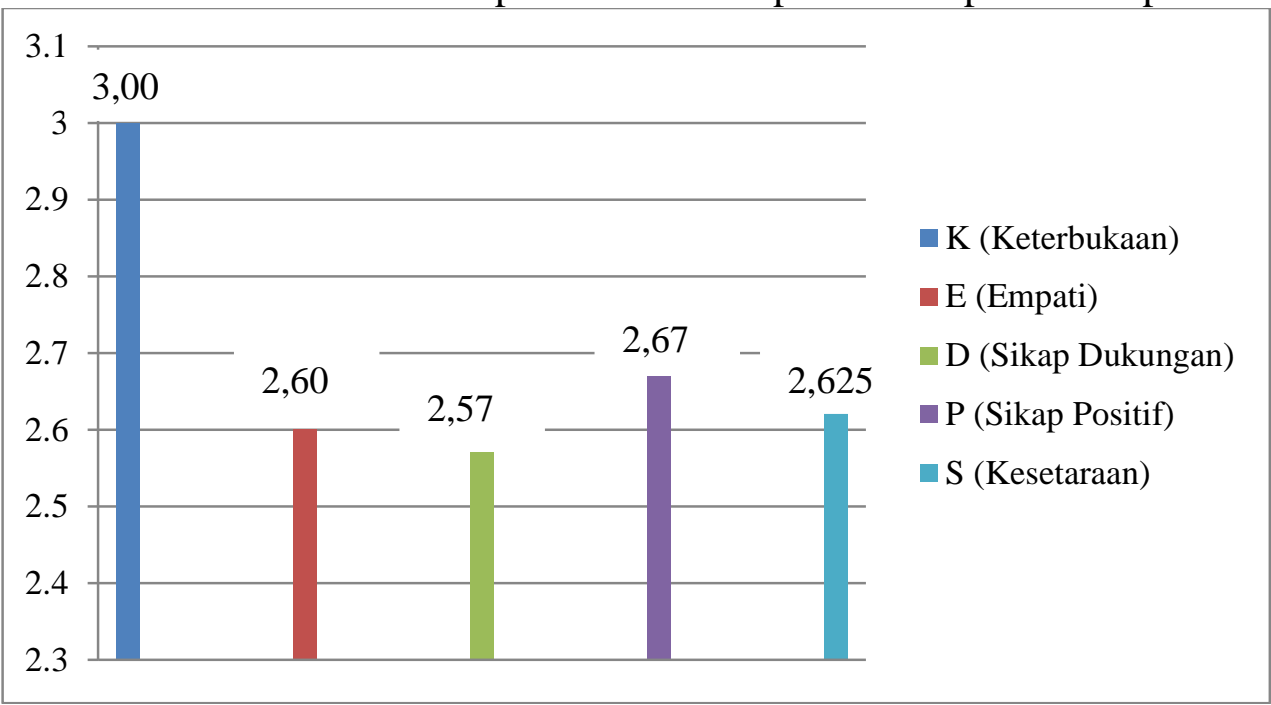

Gambar 3. Skor Rata-rata Perindikator Keterampilan Komunikasi Interpersonal

Berdasarkan Gambar 3 di atas, menjelaskan bahwa perolehan rata-rata skor pada tiap indikator keterampilan komunikasi interpersonal siswa. Perolehan dimensi K (keterbukaan) sebesar 3,00; E (empati) sebesar 2,60; D (sikap dukungan) sebesar 2,57; P (sikap positif) sebesar 2,67; dan S (kesetaraan) sebesar 2,625. Perolehan skor tertinggi pada dimensi keterampilan komunikasi interpersonal yaitu $\mathrm{K}$ (keterbukaan) sedangkan skor terendah terletak pada dimensi D (dukungan). Pada dimensi keterbukaan sebagian siswa didik mampu berinteraksi dengan siswa lain yang berkaitan dengan pembelajaran terutama pada sub materi sel. Akan tetapi untuk 
dimensi dukungan, sebagian besar siswa masih kurang memahami perasaan orang lain dan tidak memberikan apresiasi pada temannya yang memperoleh nilai tinggi pada sub materi sel. Sejalan dengan hal tersebut Pramestaningtyas, Lestari, \& Naryoso, (2014) memaparkan bahwa sebagian besar siswa telah memiliki keterbukaan yang baik mampu berinteraksi dengan siswa lain dan berperan aktif selama pembelajaran yang berkaitan dengan pembelajaran sub materi sel.
Sedangkan untuk dimensi dukungan sebagian besar siswa masih minim dalam komitmen untuk mendukung terselenggaranya interaksi secara terbuka, tidak bersikap jujur kepada orang lain, kurang memahami perasaan orang lain dan cenderung memaksakan pendapat sendiri tanpa melihat sudut pandang orang lain.

Selanjutnya, untuk penentuan kategorisasi hasil belajar siswa dapat digambarkan dalam diagram kategorisasi yang dapat dilihat pada Gambar 4.

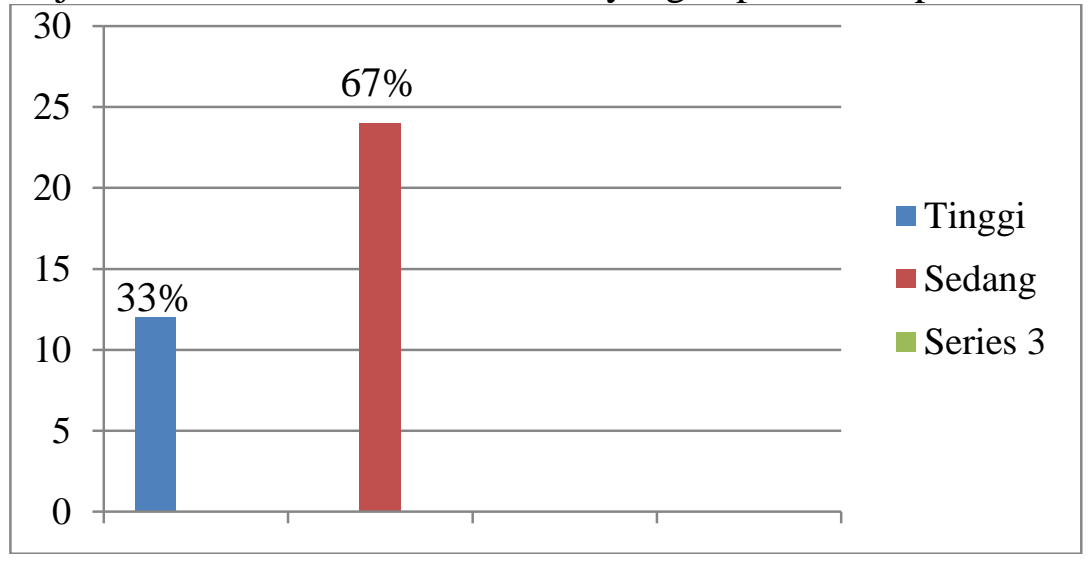

Gambar 4. Diagram Kategorisasi Hasil Belajar Siswa

Berdasarkan hasil kategorisasi hasil belajar siswa pada Gambar 4, siswa yang memiliki kategori hasil belajar tinggi yaitu sebanyak 12 orang (33\%). Sedangkan untuk kategori hasil belajar sedang yaitu sebanyak 24 orang $(67 \%)$ dan untuk kategori hasil belajar rendah tidak ada yang masuk dalam kategori tersebut. Maka dapat disimpulkan bahwa, kecenderungan variabel hasil belajar siswa di kelas XI MIPA 5 berada pada kategori sedang, yaitu sebanyak 24 orang $(67 \%)$ dari jumlah sampel berjumlah 36 orang.

Nilai yang didapatkan siswa sangat beragam. Sejalan dengan hal tersebut, Hernawati \& Hardin, (2019) memaparkan bahwa secara garis besar terdapat faktorfaktor yang mempengaruhi hasil belajar, yaitu faktor internal dan faktor eskternal.

\section{KESIMPULAN}

Kesimpulan yang diperoleh ada hubungan antara keterampilan komunikasi interpersonal dan hasil belajar siswa pada materi sel di kelas XI MIPA SMA Negeri 6 Kota Tasikmalaya Tahun Ajaran
2019/2020. Nilai koefisien korelasi (R) sebesar 0,509 yang menunjukan derajat korelasi termasuk ke dalam kategori cukup kuat, dan positif yang berarti semakin tinggi keterampilan komunikasi interpersonal siswa, maka hasil belajar siswa akan semakin tinggi. Adapun persamaan regresi yang diperoleh adalah $\hat{Y}=58,921+0,212 x$. Banyak faktor dari hasil simpangan eror, untuk itu perlu dijadikan penelitian pengembangan selanjutnya.

\section{DAFTAR PUSTAKA}

Creswell, J. W., \& Creswell, J. D. (2018). Research and Design Qualitative, Quantitative and Mixed Methods Approaches. Thousand Oaks California.

Erozkan, A. (2013). The effect of communication skills and interpersonal problem solving skills on social self-efficacy. Kuram ve Uygulamada Egitim Bilimleri.

Fatriani, M. D. (2015). Hubungan antara konsep diri dengan kemampuan 
komunikasi interpersonal pada remaja. Keefektifan Penerapan Pendekatan Keterampilan Proses Dalam Pembelajaran IPA Terhadap Minat Belajar Siswa Kelas IV SD Negeri Golo Yogyakarta.

Fraenkel, J. R. dan N. E. W. (2010). How to Design and Evaluate Research in Education (7th ed.). New York: McGraw-Hill.

Gupta, D., Mehta, M., \& Sagar, R. (2015). Interpersonal skills. In A Practical Approach to Cognitive Behaviour Therapy for Adolescents. https://doi.org/10.1007/978-81-3222241-5 5

Hargie, O. (2016). Skilled Interpersonal Communication. Skilled Interpersonal Communication.

https://doi.org/10.4324/97813157419 01

Hernawati, D., \& Hardin, A. R. (2019). Perbandingan Gaya Belajar Terhadap Keterampilan Proses Sains Peserta Didik., 1(2), 60-65.

Larasati, K., \& Marheni, A. (2019). Hubungan Antara Komunikasi Interpersonal Orangtua-Remaja Dengan Keterampilan Sosial Remaja. Jurnal Psikologi Udayana. Https://Doi.Org/10.24843/Jpu.2019.V 06.I01.P09

Lesmana, A. (2019). Hubungan Kecerdasan Logis Matematis Dan Komunikasi Interpersonal Terhadap Hasil Belajar Matematika Smp School Of Universe. Jurnal Teknologi Pendidikan. Https://Doi.Org/10.32832/Tek.Pend.V 8 i1.1722

Maryanti, S., Zikra, ., \& Nurfarhanah, . (2012). Hubungan Antara Keterampilan Komunikasi Dengan Aktivitas Belajar Siswa. Konselor. Https://Doi.Org/10.24036/020121270 0-0-00

Mufidah, I., \& Asmawi, H. (2017). Komunikasi Interpersonal Dan Keterampilan Memberi Penguatan: Sebuah Analisa Korelasional Terhadap Minat Belajar Siswa. Palapa.
Https://Doi.Org/10.36088/Palapa.V5i 2.43

Pakpahan, T. R., Hernawati, D., \& ... (2020). Analisis Miskonsepsi Peserta Didik Pada Materi Sistem Saraf Menggunakan Four-Tier Diagnostic Test. Bioeduscience.

Pramestaningtyas, E., Lestari, S. B., \& Naryoso, A. (2014). Memahami Komunikasi Antarpribadi Guru, Orang Tua Karier, Dan Anak Remaja Dalam Berinteraksi Untuk Pencapaian Prestasi Sekolah. Interaksi Online.

Pratiwi, I. D., \& Laksmiwati, H. (2016). Kepercayaan Diri Dan Kemandirian Belajar Pada Siswa Sma Negeri "X." Jurnal Psikologi Teori Dan Terapan. Https://Doi.Org/10.26740/Jptt.V7n1.P 43-49

Putriana, N. A., \& Saragih, Y. B. (2020). Pendidikan Interprofessional Dan Kolaborasi Interprofesional. Majalah Farmasetika.

Https://Doi.Org/10.24198/Mfarmaseti ka.V5i1.25626

Rianatha, L., \& Sawitri, D. R. (2015). Hubungan Antara Komunikasi Interpersonal Guru-Siswa Dengan Self-Regulated Learning Pada Siswa Sman 9 Semarang. Empati.

Sapril. (2011). Komunikasi Interpersonal. Manajemen Komunikasi.

Sara, S., Suhendar, S., \& Pauzi, R. Y. (2020). Profil Higher Order Thinking Skills (Hots) Siswa Sekolah Menengah Pertama (Smp) Kelas Viii Pada Materi Sistem Pernapasan. Bioedusiana: Jurnal Pendidikan Biologi. Https://Doi.Org/10.34289/Bioed.V5i1 .1654

Setyaningrum, D., \& Lestari, S. P. (2017). Korelasi Komunikasi Interpersonal Guru Dengan Siswa Terhadap Motivasi Belajar Di Sdn Ngijo 2 Gunungpati. Jurnal Egaliter.

Suhanti, I. Y., Puspitasari, D. N., \& Noorrizki, R. D. (2018). Keterampilan Komunikasi Interpersonal Mahasiswa Um. Prosiding Seminar Nasional Psikologi Klinis.

Utomo, D., \& Harmiyanto, H. (2016). 
Hubungan Keterampilan Komunikasi Interpersonal Dan Kepercayaan Diri Siswa Kelas X Sman 1 Garum Kabupaten Blitar. Jurnal Kajian Bimbingan Dan Konseling. Https://Doi.Org/10.17977/Um001v1i2 2016p055

Wijaya, I. S. (2013). Komunikasi Interpersonal Dan Iklim Komunikasi. Jurnal Dakwah Tabligh.
Wisman, Y. (2017). Komunikasi Efektif Dalam Dunia Pendidikan. Jurnal Nomosleca.

Https://Doi.Org/10.26905/Nomosleca. V3i2.2039

Wood, J. T. (2013). Komunikasi Interpersonal Interaksi Keseharian. Acta Universitatis Agriculturae Et Silviculturae Mendelianae Brunensis. 